\title{
Globe
}

Revue internationale d'études québécoises

\section{Études culturelles}

\section{Daniel Chartier}

Volume 1, numéro 2, 1998

URI : https://id.erudit.org/iderudit/1000509ar

DOI : https://doi.org/10.7202/1000509ar

Aller au sommaire du numéro

Éditeur(s)

Globe, Revue internationale d'études québécoises

ISSN

1481-5869 (imprimé)

1923-8231 (numérique)

Découvrir la revue

Citer ce document

Chartier, D. (1998). Études culturelles. Globe, 1(2), 7-7.

https://doi.org/10.7202/1000509ar d'utilisation que vous pouvez consulter en ligne.

https://apropos.erudit.org/fr/usagers/politique-dutilisation/ 


\title{
Présentation du numéro Études culturelles
}

\author{
Daniel Chartier \\ Université de La Sarre
}

Ce second numéro de notre revue présente des études libres portant sur différents aspects de la culture québécoise. Dans un premier article, Paola Ruggeri analyse l'américanité et les frontières nordiques dans Cowboy de Louis Hamelin. Elle constate que le Nord représente au Québec uun repère géographique essentiel pour la rencontre de l'autre, l'Autochtone». Louis LeVasseur retrace comment l'évolution des umodes de légitimation de l'enseignement de la philosophie ont changé des années 70 aux années 90 ». Quant à Claire Le Brun, elle circonscrit la place qu'occupe la littérature pour la jeunesse dans le champ littéraire au Québec, et elle dévoile les stratégies adoptées par les auteurs pour légitimer leur production. Enfin, Fernand Cloutier et Jacques Hamel observent la montée en puissance des francophones dans l'économie du Québec, à partir de la culture d'entreprise observée chez Cascades. 